\title{
A Study of Human Thermal Comfort, Ozone and Respiratory Diseases in Children
}

\author{
Amaury de Souza*, Flavio Aristone, Luciane Fernandes \\ Institute of Physics, Federal University of Mato Grosso do Sul, \\ Campo Grande, Brazil \\ Email: amaury.de@uol.com.br
}

Received 2 August 2014; revised 1 September 2014; accepted 2 October 2014

Copyright (C) 2014 by authors and Scientific Research Publishing Inc.

This work is licensed under the Creative Commons Attribution International License (CC BY). http://creativecommons.org/licenses/by/4.0/

\section{(c) (i) Open Access}

\begin{abstract}
Objective: To assess the impact of air pollution and ozone on morbidity due to respiratory diseases among children from 2005 to 2008 . Methods: The database was composed by daily reports on visits by children with respiratory diseases in health units of the Unified Health System (SUS) in the municipality of Campo Grande, MS, Brazil, by daily levels of ozone concentration measured by the Department of Physics, Federal University of Mato Grosso do Sul, and by daily measurements of temperature and relative humidity provided by the Agricultural Research CorporationEMBRAPA Gado de Corte-MS. The relationship between respiratory diseases and ozone concentration was investigated through Generalized Linear Models (GLM) using the multiple Poisson regression model. The significance level $\alpha=5 \%$ was adopted for all tests. Results: It was observed that the association between ozone (lagged by three time-steps) and attendance for respiratory diseases in children was statistically significant. The bio-meteorological variable Wind-adjusted Effective Temperature (lagged by four time-steps) was also significantly associated with diseases. Conclusions: The results suggest that the surface ozone concentration promotes adverse effects on children's health even when pollutant levels are below the amounts permitted by law.
\end{abstract}

\section{Keywords}

Air Pollution, Adverse Effects, Child Health (Public Health), Respiratory Diseases, Temperature, Lag

\section{Introduction}

Problems arising from atmospheric pollution began to be considered as a public health issue following the Industrial Revolution, when people began to be concentrated in the urban structures that we know today. The

\footnotetext{
"Corresponding author.
} 
level of city population in Brazil reached 87\% by 2010 and the cities of the developing world will make up 81 per cent of urban humanity [1].

Atmospheric pollution has affected population health, even where the levels are found to satisfy current legislation. The age-bands most affected are children [2]-[4] and the elderly [5]-[8]; both of the groups are most susceptible to the deleterious effects of pollution. Some studies have shown a positive association between mortality by respiratory diseases and atmospheric pollution [2]-[4].

The limited information currently available on the relation between atmospheric pollution and respiratory diseases in cities was the motivation for the work reported here. Its objective was to explore the relation between ozone concentration and the number of hospital admissions for diseases of the respiratory tract in children from the city of Campo Grande-MS, Brazil.

\section{Methods}

The work is an ecological study of time series from the township of Campo Grande in the State of Mato Grosso do Sul. Records of out-patient visits to the city's health centers were obtained from the Secretary for Municipal Health, and were used to establish attendances by children in the 0 to 14-year age-group. The period of analysis ran from the first of January 2005 to 31 December 2008. Respiratory diseases were coded using the $9^{\text {th }}$ Revised International Classification of Diseases (CID-9 460 to 519).

The city of Campo Grande (20 $27^{\prime} 16^{\prime \prime} \mathrm{S} ; 54^{\circ} 47^{\prime} 16^{\prime \prime} \mathrm{W}$, altitude $\left.650 \mathrm{~m}\right)$ is sited on the Maracaju-Campo Grande plateau, $150 \mathrm{~km}$ from the beginning of the largest flood-plain in the world, the Mato Grosso Pantanal (area 139 $111 \mathrm{~km}^{2}$ ). The region is tropical with high temperatures predominating throughout the year, high rainfall and high relative humidity. Mean annual temperature in the city is $23.5^{\circ} \mathrm{C}$ and mean annual rainfall is $1396 \mathrm{~mm}$; mean humidity is $71 \%$, varying over the year between $64.7 \%$ and $79 \%$. Winds are predominantly from the north (N), followed by north-east (NE) and east (E) [9].

Mean summer temperature is $25.2^{\circ} \mathrm{C}$, with maximum temperatures varying between $35.8^{\circ} \mathrm{C}$ and $37^{\circ} \mathrm{C}$ and minimum temperatures between $9.8^{\circ} \mathrm{C}$ and $12.8^{\circ} \mathrm{C}$. Summer rainfall is high, averaging $552.9 \mathrm{~mm}$ whilst relative humidity and atmospheric pressure vary little, and are always high. In winter, temperatures are more agreeable and tend to be uniform over the city; rainfall, relative humidity and atmospheric pressure are lower. Mean winter temperature varies between $20.3^{\circ} \mathrm{C}$ and $22.2^{\circ} \mathrm{C}$; temperature maxima range between $34.8^{\circ} \mathrm{C}$ and $39^{\circ} \mathrm{C}$, with minima between $-1^{\circ} \mathrm{C}$ and $3^{\circ} \mathrm{C}$. Records show that mean rainfall in winter is $108.7 \mathrm{~mm}$. Relative humidity varies between $58.5 \%$ and $70.9 \%$ [10].

The pollutant taken for study was ozone concentration $\left(\mathrm{O}_{3}\right.$ in $\left.\mathrm{ppb}\right)$ present in the atmosphere during the period 2005 to 2008, measured daily at the monitoring station of the Physics Department of the Federal University of Mato Grosso do Sul. Measures were recorded every 15 minutes through each 24-hour day to give ozone concentrations. Daily mean concentrations were calculated and were taken as estimates of air pollution within Campo Grande city. Information on rainfall, temperature, humidity and wind-speed were obtained from the EMPRAPA research station for beef production in Campo Grande.

The level of human heat comfort (CTH) is measured in terms of comfort indices, otherwise called bio-meteorological indices. The present work used the two indices Effective Temperature (ET), and Wind-adjusted Effective Temperature (WET). ET is calculated from the meteorological parameters temperature and humidity; WET uses these parameters together with wind-speed. These two indices were chosen because they give an acceptable representation of climate.

Quantitative variables were summarized in terms of measures of central tendency (mean, median) and dispersion (standard deviation) and coefficient of variation; modeling was in terms of Generalized Linear Models (GLMs) using Poisson Multiple Regression (PMR).

In PMR, the dependent variable (the number of hospital admissions) is a counting process: that is, it is a discrete quantitative variable. The independent variables are candidate variables for explaining the behavior of the series through time. These independent variables were meteorological variables (maximum, minimum and mean temperatures; humidity of the air; CTH indices; wind-speed and rainfall). The response variable in a Poisson regression should follow a Poisson distribution in which the mean of the response variable is equal to its variance. This may not always occur when analyzing experimental data, when over-dispersion (variance greater than the mean) or under-dispersion (variance less than the mean) may occur. It is still possible to use Poisson regression 
after data transformation [11] [12].

The biological effects of pollution and climate variables on human health appear to show a time-lag beginning at the time of exposure to polluting and climate agents. The hospital appearances on a specific day can therefore be associated with both the pollution level and climate variables of that day, and in preceding days. It is therefore necessary to determine the "lag" structure [13].

Before fitting the PMR, correlations with lagged variables were calculated to allow for the fact that subjects' respiratory diseases can be out of phase with pollution and climate forcing variables. The lags used were from one to seven days, since the object of the study was to determine whether correlations existed between the numbers of hospital admissions and environmental variables up to the start of the preceding week. The correlation matrix was therefore calculated between variables used in the study and their lagged series, so as to determine which variables should enter the model as measured by their statistical significance, and to explore whether collinearity existed between the independent variables.

A Poisson Regression Model on each independent variable separately was used to determine which meteorological variables were relevant at the $\mathrm{P}<0.25$ significance level; those that were, were then used in a Poisson Multiple Regression Model given by the following equation:

$$
\ln (\text { PNECRIAN })=a+\operatorname{Sbi}(X i)
$$

where PNECRIAN is the dependent variable (the number of hospital admissions with respiratory disease for child in the city of Campo Grande), $\alpha$ and $\beta$ are parameters to be estimated, and the Xi are the independent variables.

PRMs were fitted for the groupings week-day, public holiday, and year. Relative risk (RR) was calculated using the fitted model parameters by means of:

$$
R R=\exp \left(\beta^{*} X\right)
$$

where $X$ is the value of the independent variables and $\beta$ is the parameter estimated by the Poisson regression. The $95 \%$ confidence interval for the estimated parameter $\beta$ is given by the following:

$$
\mathrm{CI} 95 \%=\exp [\beta \pm 1.96 * \operatorname{SE}(\beta)]
$$

where SE is the standard error of the estimated $\beta$.

\section{Results}

During the study period, 4691 children were treated for pneumonia defined according to Chapter VIII of CID-9. Figure 1 shows that between 2005 and 2008 the pollutant ozone $\mathrm{O}_{3}$ did not exceed the daily limit for air quality, 80 ppb, defined by Conama, the National Council for the Environment.

Table 1 shows descriptive statistics for the variables number of children with pneumonia, daily levels of ozone pollution, maximum, minimum and mean air temperatures, relative humidity of air, and bio-meteorological indices.

Ozone air pollution is positively correlated with respiratory disease (Table 2). The table also shows a proportional inverse relation between diseases and climatic indicators, except for wind-speed, for which the correlation is positive.

Table 3 shows the model with greatest statistical significance, having the least AIC (Akaike Information Criterion). The smaller the AIC statistic, the better is the model at representing the relation between explanatory variables and the response variable. The model in Table 3 was found to be most efficient for predicting the number of hospital admissions for respiratory diseases in the city of Campo Grande. It can be seen that the association between ozone (lagged by three time-steps), and attendance for respiratory disease was statistically significant. Table 3 also shows that the variable Minimum WET (the bio-meteorological variable, lagged by four timesteps) is also significant.

Figure 2 shows that, for the lag period used, ozone has a positive and significant association with the disease. Figure 3 shows the percentage increase in admissions resulting from increased ozone concentration.

Figure 4 shows the negative association between number of admissions of children with respiratory disease and the index Minimum WET; Figure 5 shows the percentage decrease in number of admissions. 


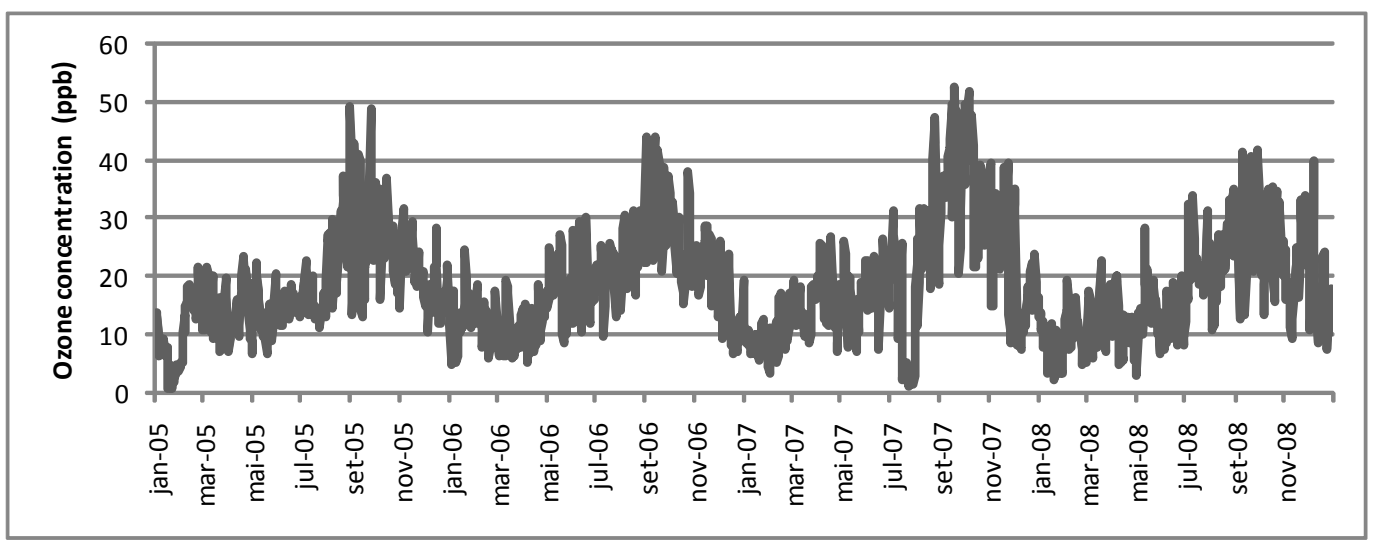

Figure 1. Mean daily concentrations of pollutants analyzed during 2005-2008, for the city of Campo Grande.

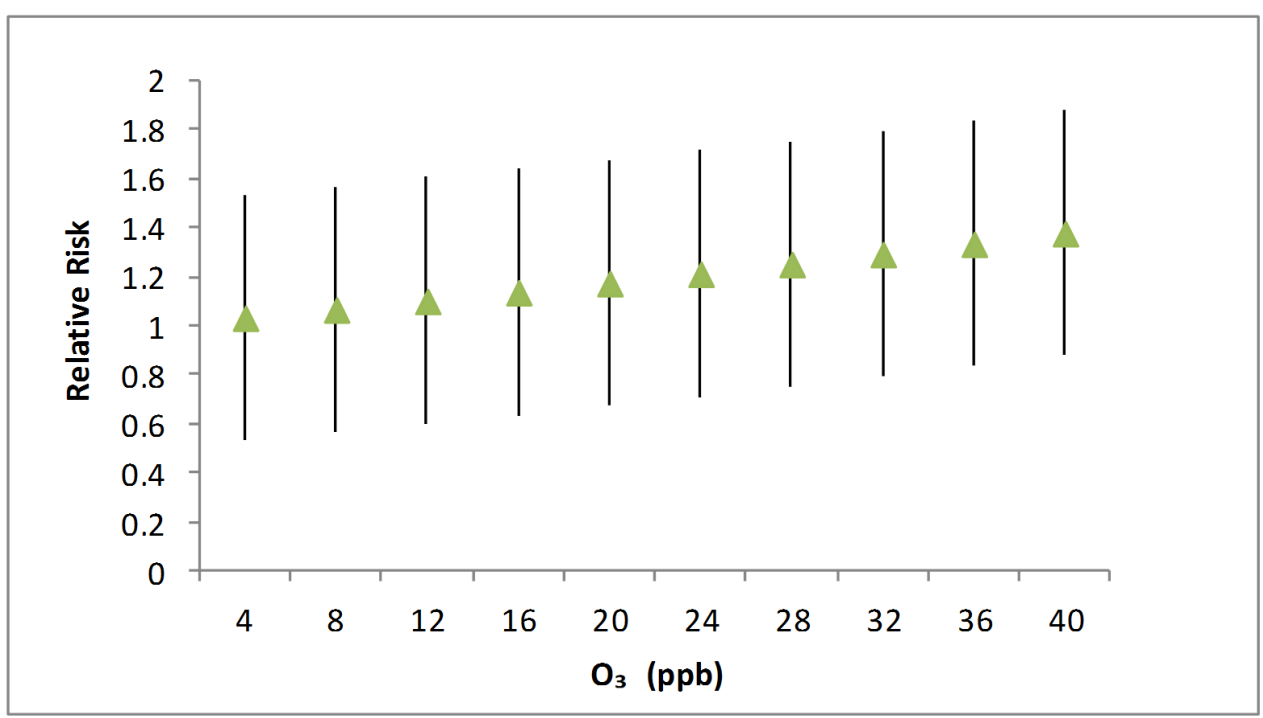

Figure 2. Relative risk resulting from increased ozone $\left(\mathrm{O}_{3}\right)$.

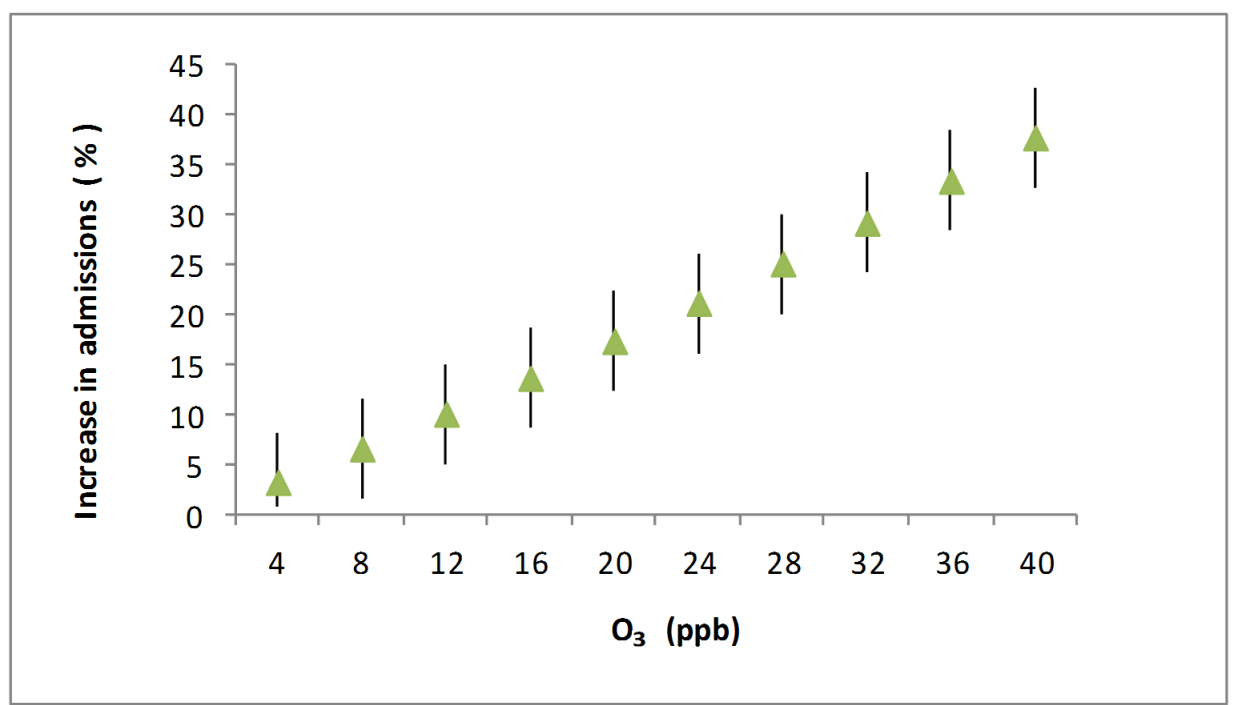

Figure 3. Increase in admissions with increasing ozone level $\left(\mathrm{O}_{3}\right)$. 


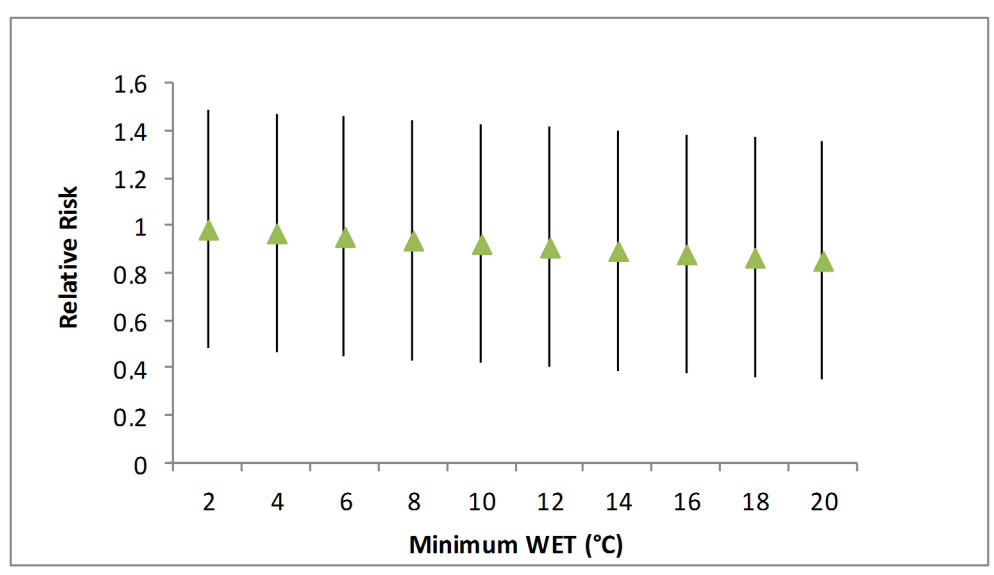

Figure 4. Relative risk for the index minimum WET.

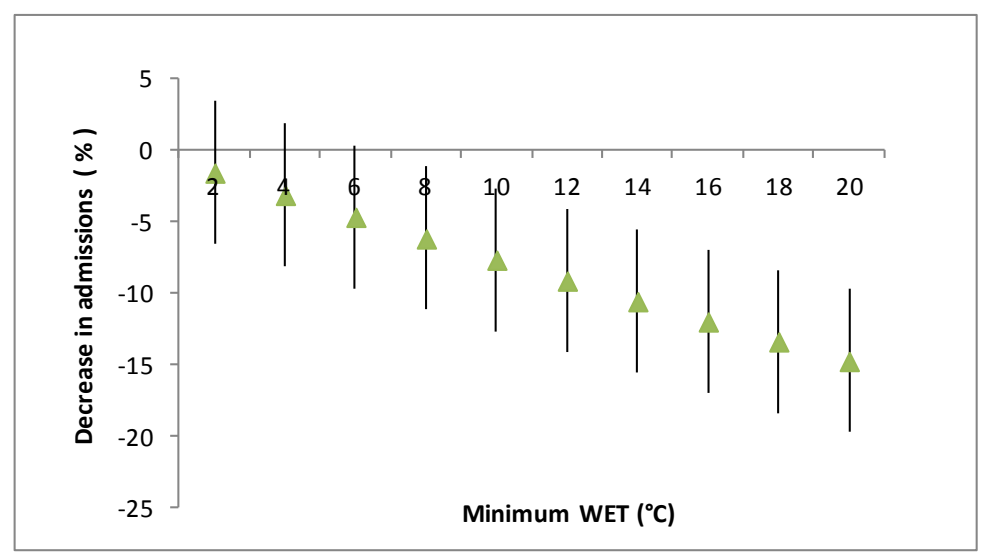

Figure 5. Decrease in admissions with increase in the index minimum WET.

Table 1. Descriptive statistics—Campo Grande-MS, 2005-2008.

\begin{tabular}{|c|c|c|c|c|c|}
\hline Variable & Mean & Minimum & Maximum & Standard deviation & $\mathbf{N}$ \\
\hline PNECRIAN $\left(\mathrm{n}^{\circ}\right)$ & 3.21 & 0 & 9 & 2.04 & 1461 \\
\hline Ozone (ppb) & 18.42 & 0.66 & 52.76 & 9.23 & 1461 \\
\hline Rainfall (mm) & 3.66 & 0.00 & 97.80 & 9.83 & 1461 \\
\hline Minimum Temp. $\left({ }^{\circ} \mathrm{C}\right)$ & 18.88 & 4.66 & 26.88 & 3.61 & 1461 \\
\hline Maximum Temp. $\left({ }^{\circ} \mathrm{C}\right)$ & 30.17 & 11.10 & 38.30 & 3.77 & 1461 \\
\hline Mean Temp. $\left({ }^{\circ} \mathrm{C}\right)$ & 23.49 & 10.00 & 30.81 & 3.43 & 1461 \\
\hline Humidity (\%) & 65.43 & 19.16 & 98.00 & 16.30 & 1461 \\
\hline Wind-speed (m/s) & 3.85 & 0.00 & 11.10 & 1.77 & 1461 \\
\hline Maximum ET $\left({ }^{\circ} \mathrm{C}\right)$ & 27.27 & 11.04 & 32.76 & 2.98 & 1461 \\
\hline Minimum ET $\left({ }^{\circ} \mathrm{C}\right)$ & 17.67 & 5.42 & 23.25 & 3.18 & 1461 \\
\hline Mean ET $\left({ }^{\circ} \mathrm{C}\right)$ & 21.58 & 10.00 & 26.31 & 2.90 & 1461 \\
\hline Maximum WET $\left({ }^{\circ} \mathrm{C}\right)$ & 25.02 & 0.45 & 32.56 & 4.33 & 1461 \\
\hline Minimum WET $\left({ }^{\circ} \mathrm{C}\right)$ & 9.48 & -7.73 & 19.06 & 4.32 & 1461 \\
\hline Mean WET $\left({ }^{\circ} \mathrm{C}\right)$ & 17.17 & -1.58 & 25.21 & 4.29 & 1461 \\
\hline
\end{tabular}


Table 2. Correlations between ozone, climatic variables, bio-meteorological indices and respiratory diseases.

\begin{tabular}{cc}
\hline Variable & PNECRIAN \\
Ozone & 0.135 \\
Precipitation & -0.076 \\
Humidity & -0.174 \\
Wind-speed & 0.096 \\
Maximum ET & -0.028 \\
Minimum ET & -0.092 \\
Mean ET & -0.046 \\
Maximum WET & -0.007 \\
Minimum WET & -0.049 \\
Mean WET & -0.034 \\
\hline
\end{tabular}

Table 3. Regression coefficients, relative risk and 95\% confidence intervals for ozone in the model.

\begin{tabular}{|c|c|c|c|c|c|}
\hline \multirow[t]{2}{*}{ Parameters } & \multirow[t]{2}{*}{ Regression coefficient } & \multirow[t]{2}{*}{ Standard error } & \multirow[t]{2}{*}{ Relative risk } & \multicolumn{2}{|c|}{$\begin{array}{l}95 \% \text { Confidence interval for exp } \\
\qquad(\boldsymbol{B})\end{array}$} \\
\hline & & & & Lower & Upper \\
\hline Intercept & -0.251 & 0.0489 & 0.778 & -0.346 & -0.155 \\
\hline Ozone & 0.008 & 0.0011 & 1.008 & 0.006 & 0.010 \\
\hline [Weekday = 0] & 1.667 & 0.0375 & 5.297 & 1.594 & 1.741 \\
\hline [Public holiday = 1] & $0^{\mathrm{a}}$ & - & 1 & - & - \\
\hline [Year 2005] & -0.040 & 0.0292 & 0.960 & -0.098 & 0.017 \\
\hline [Year 2006] & -0.100 & 0.0315 & 0.905 & -0.161 & -0.038 \\
\hline [Year 2007] & -0.038 & 0.0296 & 0.962 & -0.096 & 0.020 \\
\hline [Year 2008] & $0^{\mathrm{a}}$ & - & 1 & - & - \\
\hline Minimum WET & -0.008 & 0.0024 & 0.992 & -0.012 & -0.003 \\
\hline
\end{tabular}

\section{Discussion}

Although this paper reports an ecological study in which the unit studied is the group of individuals representative of a district, city or even a country and not individual observation, it must be emphasized that these studies have been shown to be efficient for analysis of the effects of pollution on health [3] [4] [6]-[8] [13]. The option of working with the total number of respiratory diseases and not with each specific pathology, rests on the probability of reducing the range of various services supplying the original data. Through the use of increasingly-sophisticated regression models, confounding factors which could interfere with the data analysis could be more efficiently controlled. Generalized Linear Models (GLMs) were used to describe the relation between response and explanatory variables, in particular by using Poisson Multiple Regression because the response variable was a counting variable, quantitative and discrete, representing the number of admissions for respiratory disease [14].

The independent variables described behavior of the series through time. These were meteorological variables (maximum and minimum temperatures and humidity; human heat comfort index CTH; wind-speed and rainfall). Variables "Day in the week" and "Public holiday" were used to control short-duration seasonality, whilst the variable "Year" was used to control longer-term seasonality. 
Positive associations were found between ozone level and infant respiratory disease in Campo Grande. These effects are similar to those found in other Brazilian cities, especially in São Paulo [2]-[4] in terms of both the diversity of pollutants and the magnitude of the estimated effects.

The increased incidence of respiratory disease under winter conditions is due to two main factors: the low temperatures, and the increases in concentrations of primary pollutants [5] [7] [8] [13]. Ozone $\mathrm{O}_{3}$ is a secondary pollutant which depends on the presence of solar radiation and on precursors, such as nitrogen oxides and hydrocarbonates. Dry winters with sunny days satisfy all the conditions for increased levels of this photochemical agent, as in other seasons of the year. Thus, $\mathrm{O}_{3}$ does not show high correlation with other variables included for analysis in the present study. Nevertheless its oxidizing action and its capacity to induce inflammation give it an active role in causing and aggravating respiratory diseases, as reported in other studies [3] [4].

Based on the results found it can be concluded that, although levels of air pollution in Campo Grande are not very high and do not exceed standards above which air is regarded as polluted, they are nevertheless associated with respiratory problems in the city's child population.

It is hoped that the results reported here will be useful in terms of measuring the risks to which the population is exposed, and for developing measures to minimize such risks, thus contributing to planning issues of environmental or urban health and the consequent development of public policy.

\section{References}

[1] State of World Population (2011) UNFPA—United Nations Population Fund. http://www.unfpa.org/swp/

[2] Braga, A.L.F., Conceição, G.M.S., Pereira, L.A.A., Kishi, H.S., Pereira, J.C.R., Andrade, M.F., et al. (1999) Air Pollution and Pediatric Respiratory Hospital Admissions in São Paulo, Brazil. Journal of Environmental Medicine, 1, 95102. http://dx.doi.org/10.1002/(SICI)1099-1301(199904/06)1:2<95::AID-JEM16>3.0.CO;2-S

[3] Braga, A.L.F., Saldiva, P.H.N., Pereira, L.A.A., Menezes, J.J.C., Conceição, G.M.S., Lin, C.A., et al. (2001) Health Effects of Air Pollution Exposure on Children and Adolescents in São Paulo, Brazil. Pediatric Pulmonology, 31, 106113. http://dx.doi.org/10.1002/1099-0496(200102)31:2<106::AID-PPUL1017>3.0.CO;2-M

[4] Lin, A.C., Martins, M.A., Farhat, S.L., Pope III, C.A., Conceição, G.M.S., Anastácio, M.V., et al. (1999) Air Pollution and Respiratory Illness of Children in São Paulo, Brazil. Paediatric and Perinatal Epidemiology, 13, 475-488. http://dx.doi.org/10.1046/j.1365-3016.1999.00210.x

[5] Atkinson, R.W., Anderson, H.R., Sunyer, J., Ayres, J., Baccini, M., Vonk, J.M., et al. (2001) Acute Effects of Particulate Air Pollution on Respiratory Admission: Results from APHEA 2 Project. Air Pollution and Health: A European Approach. American Journal of Respiratory and Critical Care Medicine, 164, 1860-1866. http://dx.doi.org/10.1164/ajrccm.164.10.2010138

[6] Martins, L.C., Latorre, M.R.D.O., Cardoso, M.R.A., Gonçalves, F.L.T., Saldiva, P.H.N. and Braga, A.L.F. (2002) Poluição atmosférica e atendimentos por pneumonia e gripe em São Paulo, Brasil. Revista de Saúde Pública, 36, 88-94. http://dx.doi.org/10.1590/S0034-89102002000100014

[7] Schwartz, J. and Marcus, A. (1990) Mortality and Air Pollution in London: A Time Series Analysis. American Journal of Epidemiology, 131, 185-194.

[8] Schwartz, J. and Dockery, D.W. (1992) Particulate Air Pollution and Daily Mortality in Steubenville, Ohio. American Journal of Epidemiology, 135, 12-19; discussion 20-25.

[9] Sant'Anna Neto, J.L. and da Anunciação, V.S. (2001) Uma reflexão do espaço urbano da cidade de Campo Grande/MS na perspectiva climática. Revista Pantaneira, Aquidauana, 3, 55-66.

[10] da Anunciação, V.S. and Sant’Anna Neto, J.L. (2002) Urban Climate of the City of Campo Grande-MS (in Portuguese). In: Sant'Anna Neto, J.L., Org., Os climas das cidades brasileiras, Editora da UNESP, Presidente Prudente, 22-35.

[11] Tadano, Y.S., Ugaya, C.M.L. and Franco, A.T. (2009) Método de regressão de Poisson: Metodologia para avaliação do impacto da poluição atmosférica na saúde populacional. Ambiente \& Sociedade, 12, 241-255. http://dx.doi.org/10.1590/S1414-753X2009000200003

[12] Coelho, M.S.Z.S., Alves, F.L.T.G. and Latorre, M.R.D.O. (2010) Statistical Analysis Aiming at Predicting Respiratory Tract Disease Hospital Admissions from Environmental Variables in the City of São Paulo. Journal of Environmental and Public Health, 2010, Article ID: 209270. http://dx.doi.org/10.1155/2010/209270

[13] Anderson, H.R., Leon, A.P., Bland, J.M., Bower, J.S. and Strachan, D.P. (1996) Air Pollution and Daily Mortality in London: 1987-1992. BMJ, 312, 665-669. http://dx.doi.org/10.1136/bmj.312.7032.665

[14] Hastie, T.J. and Tibshirani, R.J. (1995) Generalized Additive Models. Chapman and Hall, London. 
Scientific Research Publishing (SCIRP) is one of the largest Open Access journal publishers. It is currently publishing more than 200 open access, online, peer-reviewed journals covering a wide range of academic disciplines. SCIRP serves the worldwide academic communities and contributes to the progress and application of science with its publication.

Other selected journals from SCIRP are listed as below. Submit your manuscript to us via either submit@scirp.org or Online Submission Portal.
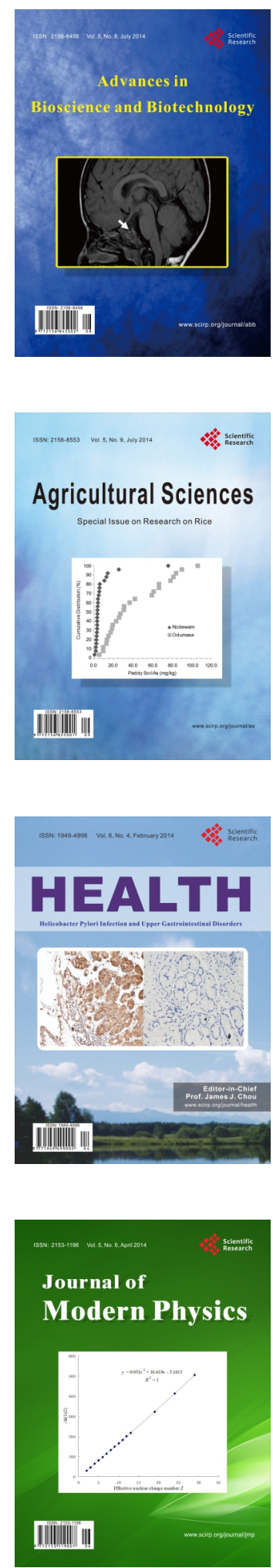
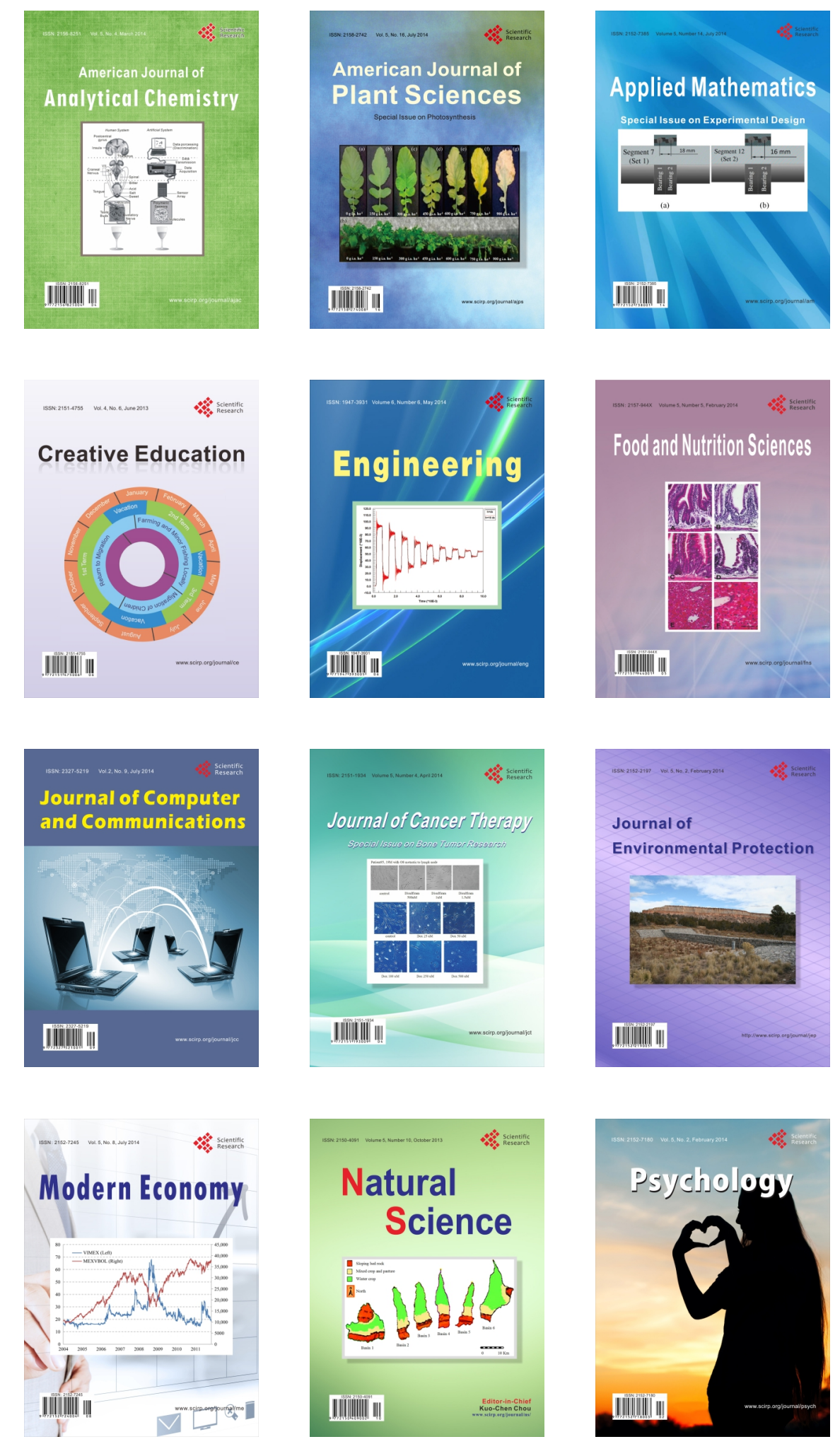